\title{
ARTICLE
}

\section{Spatial distribution of Antarctic copepods in Fíldes Bay during summer of 2012}

\author{
Distribución espacial de copépodos Antárticos en \\ Bahía Fíldes durante el verano de 2012
}

\section{Paulo F. Lagos ${ }^{1}$ and Karen Manríquez ${ }^{1}$}

\begin{abstract}
'Centro de Investigación Marina Quintay CIMARQ, Escuela de Ciencias del Mar, Facultad de Ecología y Recursos Naturales, Universidad Andres Bello, Valparaíso, Chile. k.manriquezdiaz@uandresbello.edu

Resumen.- La Península Antártica Chilena, se caracteriza por ser estable en su condición oceanográfica, sin embargo sus zonas costeras como bahías pueden presentar condiciones físicas variables tanto espacial como temporalmente. Se ha señalado que existe una importante interacción entre las condiciones oceanográficas y patrones de distribución espacial del zooplancton, sin embargo, no existe mayor evidencia acerca de cómo esta interacción afecta la distribución horizontal y vertical del zooplancton que habita estas zonas. El presente estudio muestra evidencias de los cambios que ocurren a nivel de estructura comunitaria del zooplancton, específicamente en el ensamble de copépodos al interior de Bahía Fíldes. Los resultados muestran que copépodos de la familia Oithonidae son abundantes en zonas costeras de la bahía mientras que copépodos de la familia Calanidae son abundantes en zonas contiguas al Estrecho Bransfield encontrándose en escasa abundancia al interior de la bahía. Estos hallazgos indican que existen diferencias en el ensamble de copépodos a lo largo de la bahía con cambios en términos de abundancia y distribución de grupos dominantes encontrados comúnmente en la Península Antártica y aguas cercanas al paso Drake.
\end{abstract}

Palabras clave: Península Antártica, Bahía Fíldes, copépodos, distribución

\begin{abstract}
The Antarctic Chilean peninsula, is characterized for being stable in its oceanographic conditions. Nevertheless, its coastal zones, such as bays, may have more variable physical conditions, both spatially and temporally. It has been observed that a remarkable interaction between the oceanographic conditions and spatial distribution patterns of zooplankton occurs. However, there is no good understanding of how these interactions affect the horizontal and vertical distribution of zooplankton living in these areas. The present study shows the changes that occur at the level of the zooplankton community structure, specifically in the copepods assembly of Fíldes Bay. The results show that copepods of the Oithonidae family are abundant in coastal areas of the bay meanwhile Calanidae copepods are abundant in zones adjacent to Bransfield Strait and found only in low abundance at the interior of the bay. These findings indicate differences in the ensemble of copepods along the bay with changes in the abundance and distribution of dominant groups of copepods commonly found in the Antarctic Peninsula and Drake Passage waters.
\end{abstract}

Key words: Antarctic Peninsula, Fíldes Bay, copepods, distribution

\section{INTRODUCTION}

Antarctic marine environments are characterized by low and stable temperatures with little seasonal variations of $\pm 3^{\circ} \mathrm{C}$ at low latitudes and only $\pm 0.2^{\circ} \mathrm{C}$ at high latitudes (Clarke \& Peck 1991). Despite this stability, coastal areas such as bays present oceanographic variations, which, depending on the level of variation, may modify the interaction between the physic and the spatial distribution patterns of zooplankton (Chang et al. 1990). Bonicelli et al. (2008) showed that the region of the South Shetland Islands is a dynamic area where the distribution of zooplankton is strongly related to the water masses characteristics of the Bellinghausen Sea and Southeast Weddell Sea. Here the circulation patterns associated with hydrological and meteorological features such as the Antarctic Circumpolar Current, polar fronts and their relations with sea ice and topography of the islands, determine the circulation patterns and thus control the dynamics of all zooplankton populations (Razouls et al. 2000).

Within this system, controlled by large scale ocean circulation features (Smith et al. 1999), are the South Shetland Islands, which are heavily influenced by the Weddell-Scotland eddy that moves slowly towards east and then towards south in movements associated with the countercurrent system that moves west and enters 
Drake Passage (Fontaine 1988). The Fíldes Bay, is approximately $14 \mathrm{~km}$ long and $6 \mathrm{~km}$ to $14 \mathrm{~km}$ wide, separated from the Bransfield Strait by a $430 \mathrm{~m}$ deep sill. Waters depth increases gently from the coastline to 200 to $400 \mathrm{~m}$ depth. While the shallow areas show irregular topographic features, the central basin if the bay is relatively flat with depths ranging from 400 to $500 \mathrm{~m}$. (Chang et al. 1990). The surface layer of Fíldes Bay freezes in winter and melts in summer. However, there are records of years in which coastal areas didn't freeze even during winter months (Sakurai et al. 1996) which creates changing oceanographic conditions within the bay, mainly dominated by a wide coverage of drifting icebergs entering the bay throughout the year (Battaglia et al. 2009). These icebergs provide a large amount of fresh water, which in addition to the water from the land and submerged glaciers in the bay, generate colder and less saline surface waters, with a gradual increase in temperature and salinity to the southeast and mouth of the bay (Chang et al. 1990). This variability in the oceanographic conditions present at the bay, may be influenced largely by the physical conditions that occur in the outer part of Fíldes Bay, which is open to Bransfield Strait, an area where the basic circulation pattern consists of an occasional entry of relatively warmer waters from the Bellingshausen Sea, Gerlache Strait and the Antarctic Circumpolar Current, and an eastern entry of colder and more saline waters of the Weddell Sea (Sangrá et al. 2011) therefore subjected to variations in temperature between $0.5^{\circ} \mathrm{C}$ and $-1.5^{\circ} \mathrm{C}$ that reach the southeastern coast of King George island, and temperatures of $2^{\circ} \mathrm{C}$ along the southern coast of the South Shetland islands (Zmijewska et al. 1999).

Kittel et al. (2001) noticed that oceanic conditions appear to be an important influence on the characteristics and distribution of coastal zooplankton assemblages, but, most studies of spatial distribution patterns of zooplankton abundance have focused on areas close to Weddell Sea, Bransfield Strait, Drake Passage and the Antarctic Peninsula (Zmijewska 1985, 1987; Langdon et. al. 1996, Walkusz et al. 2004, Zhou et al. 2010, Thompson et al. 2012), with little investigation of spatial distribution of zooplankton in variable areas such as bays, which represent an interesting study site at the biological level due to the variations in biological productivity and diversity of organisms. In this context, this study aims to describe the characteristics of the zooplankton community present in Fíldes Bay, specifically in the summer 2012, and its spatial variability. We propose that there are differences in the spatial distribution of zooplankton groups belonging to the meso-zooplankton along the whole bay, which respond to the high physical heterogeneity of the oceanographic conditions, which are in turn a product of the geomorphologic and climatic variability in the area.

\section{MATERIALS AND METHODS}

\section{SAMPLING}

Between December 15, 2011 and February 8, 2012, 18 zooplankton samples were obtained from three sampling stations parallel to the coastline at Fíldes Bay, King George Island $\left(62^{\circ} 12^{\prime} \mathrm{S}, 58^{\circ} 57^{\prime} \mathrm{W}\right)$. A total of 6 samples, 3 surface samples and 3 samples at $0-15 \mathrm{~m}$ depth were taken at each station. All stations were positioned approximately equidistant to each other, with the first station (ST1) at a distance of $1.47 \mathrm{~km}$ from the coast $\left(62^{\circ} 13^{\prime} 35.19^{\prime}\right.$ ' $\mathrm{S}$, $58^{\circ} 51^{\prime} 50.63$ ' W), the second station (ST2) located $4.5 \mathrm{~km}$ from the coast (62 14 '47.96' $\left.\mathrm{S}, 58^{\circ} 51^{\prime} 10.18^{\prime \prime} \mathrm{W}\right)$ and a third sample station (ST3) located at a distance of $9.6 \mathrm{~km}$ from the coast $\left(62^{\circ} 14^{\prime} 21.46^{\prime \prime} \mathrm{S}, 58^{\circ} 47^{\prime} 1.75^{\prime \prime} \mathrm{W}\right)$ (Fig. 1).

Zooplankton samples were obtained using a MK-IV Zodiak boat belonging to the Chilean Antarctic Institute (INACH). Surface samples were obtained using a floating epineustonic net with $200 \mu \mathrm{m}$ mesh with a $1.2 \times 0.5 \mathrm{~m}$ rectangular opening (see DiSalvo 1988) and for oblique tracking samples (0-15 m depth) a WP-2 network of $200 \mu \mathrm{m}$ mesh size and $60 \mathrm{~cm}$ in diameter was used, with a weight of $2 \mathrm{~kg}$ for ballast. The tows were conducted simultaneously and both nets were equipped with a flowmeter (HydroBios) to obtain the volume of filtered water. Tows were performed in triplicate at each of the stations and were performed for an approximate time of $30 \mathrm{~min}$ at a constant speed of 1 knot along transects $800 \mathrm{~m}$ long.

The samples were stored in $1 \mathrm{~L}$ plastic bottles in absolute ethanol for later analysis. In addition to the mesozooplankton samples, temperature, salinity and density profiles were obtained from each station. Data was obtained by using a CTD profiler instrument (SEABIRD SBE-19).

\section{IDENTIFICATION AND QUANTIFICATION OF ZOOPLANKTON}

The samples were identified to Family taxonomic level, with a stereo microscope (Olympus ${ }^{\circledR}$ BX 51) and quantification was performed using a Bogorov chamber. Following this, all copepods found were isolated in Eppendorf tubes and separated by net and station and 


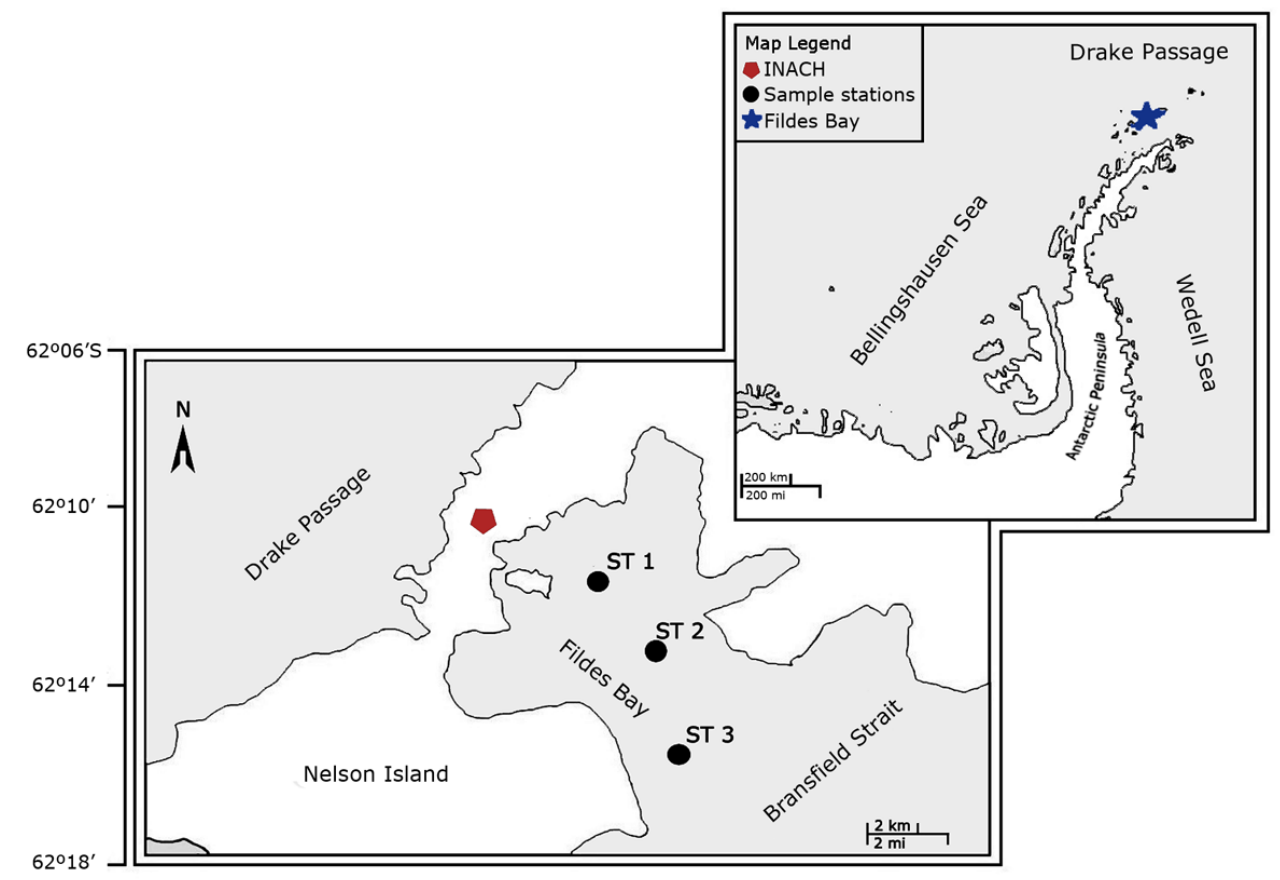

Figure 1. Sample stations used for zooplankton extractions, located along Fíldes Bay. Escudero Base (INACH), Station 1 (ST 1), Station 2 (ST 2), Station 3 (ST 3) / Estaciones de muestreo utilizadas para la extracción de zooplancton, localizadas a lo largo de la Bahía Fíldes. Base Escudero (INACH), Estación 1(ST 1), Estación 2 (ST 2), Estación 3 (ST 3)

then photographed individually and identified to Family level using taxonomic keys (Boltovskoy 1999) and databases located in OBIS ${ }^{1}$ and WoRMS ${ }^{2}$. Parallel to this, abundance (A) of copepods (ind. $1000 \mathrm{~m}^{-3}$ ) was estimated using $\mathrm{A}=1000 *$ (Abundance) /Filtered $\mathrm{Vol}\left(\mathrm{m}^{3}\right)$.

\section{DATa ANALYSiS}

To assess significant differences in the abundance of major taxa and families of copepods in different sampling stations and types of net, a two-way ANOVA analysis was performed under a general linear model (GLM) using a statistical analysis program (STATISTICA ${ }^{\circledR}$ v6.0, StatSoft, OK, USA). To analyze differences in the spatial distribution of zooplankton, we used cluster analysis with 1000 bootstrap replicates under a matched group algorithm and Euclidean similarity average, non-metric multidimensional scaling (n-MDS) (using the program PAST v 2.16 (Hammer et al. 2001). and linear correlation analysis (STATISTICA ${ }^{\circledR}$ v6.0, StatSoft, OK, USA).

\section{RESULTS}

\section{WATER COLUMN PROFILES}

Temperature differences between the sampled stations were observed (Fig. 2) with lowest temperatures occurring at the station closest to the coast, and values decreasing vertically between $1.3^{\circ} \mathrm{C}$ at the surface to $1.15^{\circ} \mathrm{C}$ at $15 \mathrm{~m}$ depth. In comparison, the surface temperatures at Stations 2 and 3 were higher with values ranging from 1.35 to $1.5^{\circ} \mathrm{C}$ in the deeper layers and between 1.4 to $1.5^{\circ} \mathrm{C}$ in surface layers of the water column. Salinity showed constant values of 34.2 at the entire water column at Station 1, while Stations 2 and 3 showed stratification in the first 4 $\mathrm{m}$ of the water column with salinity values of 34.5 at the Station 2 and salinities of 33 at the Station 3 farthest from the coast. This stratification farther from the coast is correlated to the density data.

\section{Abundance of zooplankton}

A total of 6 major zooplankton taxa were found, including 

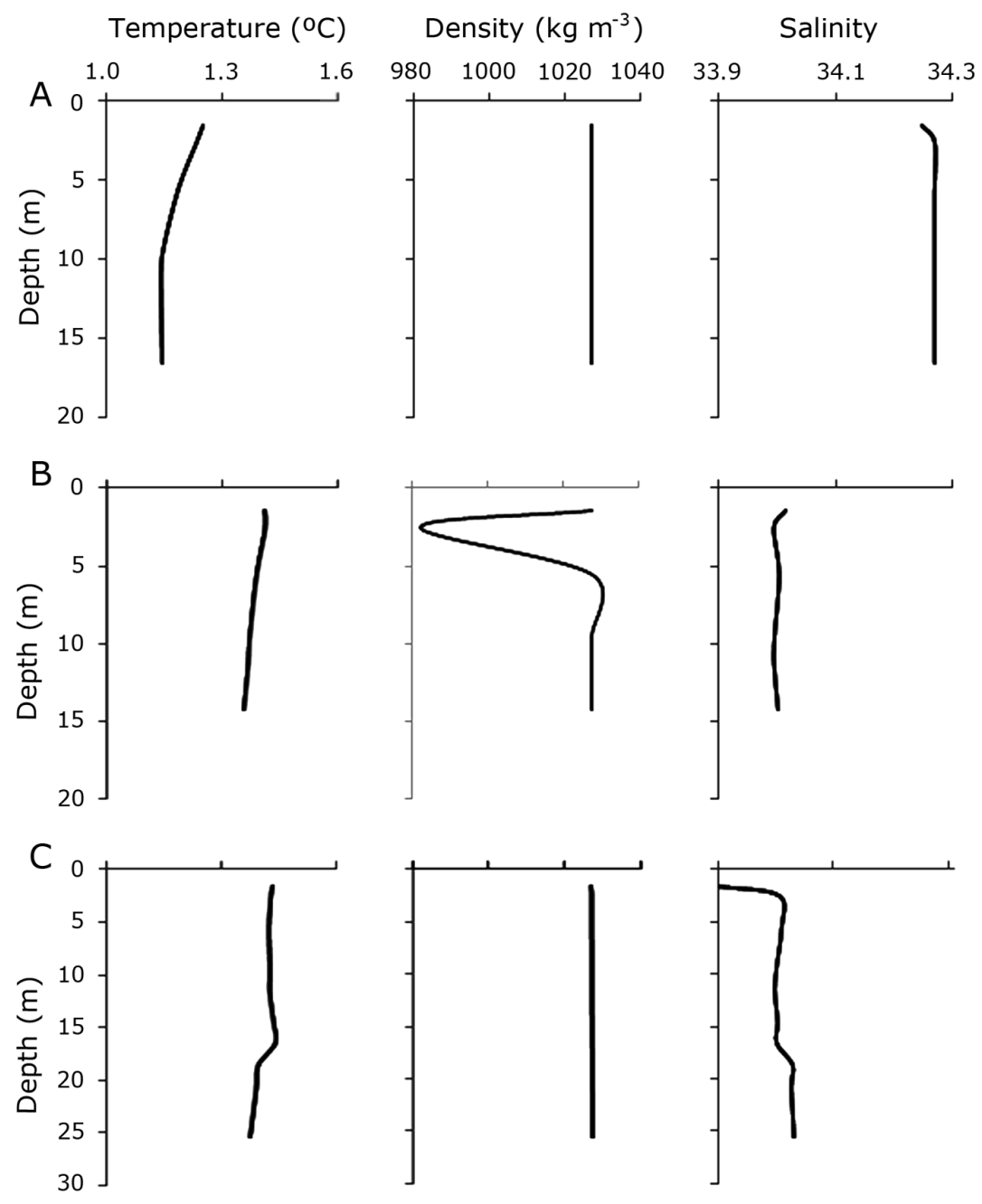

\begin{abstract}
Figure 2. Oceanographic profiles of temperature $\left({ }^{\circ} \mathrm{C}\right)$, density $\left(\mathrm{kg} \mathrm{m}^{-3}\right)$ and salinity of the water column, for A) the station near to the coast (St 1), B) middle (St 2), and C) near to Bransfield Strait (St 3) / Perfiles oceanográficos de temperatura $\left({ }^{\circ} \mathrm{C}\right)$, densidad $\left(\mathrm{kg} \mathrm{m}^{-3}\right)$ y salinidad de la columna de agua, para A) la estación cercana a la costa (St 1), B) intermedia (St 2), y C) cercana al Estrecho Bransfield (St 3)
\end{abstract}

mollusks, copepods, euphausiids, amphipods and ichthyoplankton (Table 1).

Statistical analysis showed no significant differences in terms of total abundance of copepods at different sampling stations or between samples collected with different net types (ANOVA, $\mathrm{F}_{(2,96)}=1.21, P=0.29$ ). However, when the abundance of different taxa was analyzed, significant differences between the taxa were found (ANOVA, $\mathrm{F}_{(5,6)}=7.98 P<0.05$ ), (Table 2). When the differences in the total abundance of copepods in the sampling stations and nets were analyzed, no significant differences were found (ANOVA $\mathrm{F}_{(2,11)}=2.12, P=0.16$ ), showing abundances of 262 ind. $1000 \mathrm{~m}^{-3}$ (Station 1), 139 ind. $1000 \mathrm{~m}^{-3}$ (Station 2 ) and 206 ind. $1000 \mathrm{~m}^{-3}$ (Station 3). At copepod family level, a total of 14 families were found in Fíldes Bay, including species from Cyclopinidae, Oncaeidae, Oithonidae, Candaciidae, Metridinidae, Augaptilidae, Scolecitrichidae, Phaennidae, Aetideidae, Clausocalanidae, Spinocalanidae, Eucalanidae, Calanidae and Megacalanidae. Most dominant families were 
Table 1. Abundance expressed (ind. $1000 \mathrm{~m}^{-3}$ ) of major zooplankton taxa found at two depths in each sampling station along Fíldes Bay / Abundancia (ind. $1000 \mathrm{~m}^{-3}$ ) de taxones mayores de zooplancton encontrados a dos profundidades en cada estación de muestreo de Bahía Fíldes

\begin{tabular}{|c|c|c|c|c|c|c|c|c|c|}
\hline & \multicolumn{6}{|c|}{ Abundance ind. $1000 \mathrm{~m}-3$} & \multirow{3}{*}{ Total } & \multirow{2}{*}{\multicolumn{2}{|c|}{ Net }} \\
\hline & \multicolumn{6}{|c|}{ Stations } & & & \\
\hline & ST1 EPI & ST1 WP2 & ST2 EPI & ST 2 WP2 & ST3EPI & ST 3 WP2 & & EPI & WP2 \\
\hline Molluscs & 29 & 0 & 0 & 0 & 3 & 8 & 40 & 8 & 32 \\
\hline Copepods & 1270 & 204 & 173 & 664 & 563 & 648 & 3552 & 2036 & 1516 \\
\hline Euphausiids & 21 & 0 & 0 & 0 & 3 & 8 & 32 & 24 & 8 \\
\hline Ichthyoplankton & 0 & 0 & 0 & 0 & 0 & 8 & 8 & 0 & 8 \\
\hline Amphipods & 29 & 4 & 0 & 0 & 6 & 4 & 35 & 27 & 8 \\
\hline N/Id. & 14 & 11 & 11 & 13 & 15 & 24 & 88 & 40 & 48 \\
\hline Total & 1384 & 219 & 195 & 681 & 620 & 704 & 3803 & 2175 & 1628 \\
\hline
\end{tabular}

N/id. : not identified

Table 2. General lineal model analysis (ANOVA) comparing differences in the abundance of major zooplankton taxa (S), (N) type of net and (St) sampling station. DF= degree of freedom, SS= sums of square, MS= mean squared, $F=F$ value, $P=$ Probability / Modelo lineal general (ANOVA) que compara diferencias en la abundancia de taxones mayores de zooplancton (S), (N) tipo de red y (St) estación de muestreo. $\mathrm{DF}=$ grados de libertad, $\mathrm{SS}=$ suma de cuadrados, $\mathrm{MS}=$ cuadrados medios, $\mathrm{F}=$ valor $\mathrm{F}, \mathrm{P}=$ probabilidad

\begin{tabular}{lrrrrr}
\hline & \multicolumn{1}{c}{ SS } & DF & \multicolumn{1}{c}{ MS } & F & \multicolumn{1}{c}{$P$} \\
\hline Specie (S) & 561290.6 & 5 & 112258.1 & 17.72 & $\leq 0.001$ \\
Station (St) & 8591 & 2 & 4295.5 & 0.68 & 0.51 \\
Net (N) & 2132.4 & 1 & 2132.4 & 0.34 & 0.56 \\
$(\mathrm{~S})^{*}(\mathrm{St})$ & 32707.3 & 10 & 3270.7 & 0.53 & 0.87 \\
$(\mathrm{~S})^{*}(\mathrm{~N})$ & 6924.6 & 5 & 1384.9 & 0.22 & 0.95 \\
$(\mathrm{St})^{*}(\mathrm{~N})$ & 30796.6 & 2 & 15398.3 & 2.43 & 0.10 \\
$(\mathrm{~S})^{*}(\mathrm{St})^{*}(\mathrm{~N})$ & 130859.2 & 10 & 13085.9 & 2.07 & $\leq 0.001$ \\
Error & 418167.4 & 66 & 6335.9 & & \\
\hline
\end{tabular}

Oithonidae (abundance percentage 38\%), Calanidae (26\%), Augaptilidae (13\%), together representing $77 \%$ of total copepods found at Fíldes Bay, and the remaining taxa contributed 1 to $3 \%$ each (Fig. 3).

\section{SPATIAL Distribution}

The spatial distribution analysis showed significant differences $(P \leq 0.05)$ in the abundance of the 3 most representative families, with differences associated with depth and sampling stations. When the families are separated by relative abundance, the family Oithonidae registered a greater abundance at Station 1 closest to the coast (ST1) with maximum values of abundance at the surface (EPI) and lower abundance values at 0-15 m deep (WP2). At Station 2 (ST2) a reverse of this pattern was observed, with the highest abundance in the stratum of 0-15 m deep and a minimal abundance on the surface. This pattern continues for Station 3 (ST3) nearest the Bransfield Strait but the overall values of abundance for the Family Oithonidae decreased significantly in both sampling depths (Fig. 4).

The Augaptilidae family showed a different distribution pattern to Oithonidae, with significant differences in horizontal and vertical abundance. At Station 1 closest to the coast there were no representatives of this family in the surface layer and its distribution is restricted to deeper layers of the water column. Station 2 showed a slight increase in abundance and higher densities of Augaptilidae individuals in surface layers of the water column, then at Station 3 located farthest from the coast similar relative abundances were found in both deep and shallow layers of the water column.

Finally, Calanidae had a differential spatial distribution pattern, showing a distribution with a more oceanic influence compared to the rest of the families mentioned above. At Station 1 closest to the coast and Station 2 the members of this family had low densities ranging from 724 ind. $1000 \mathrm{~m}^{-3}$ for both sampling depths. However, at Station 3 an increase in the density of individuals was 


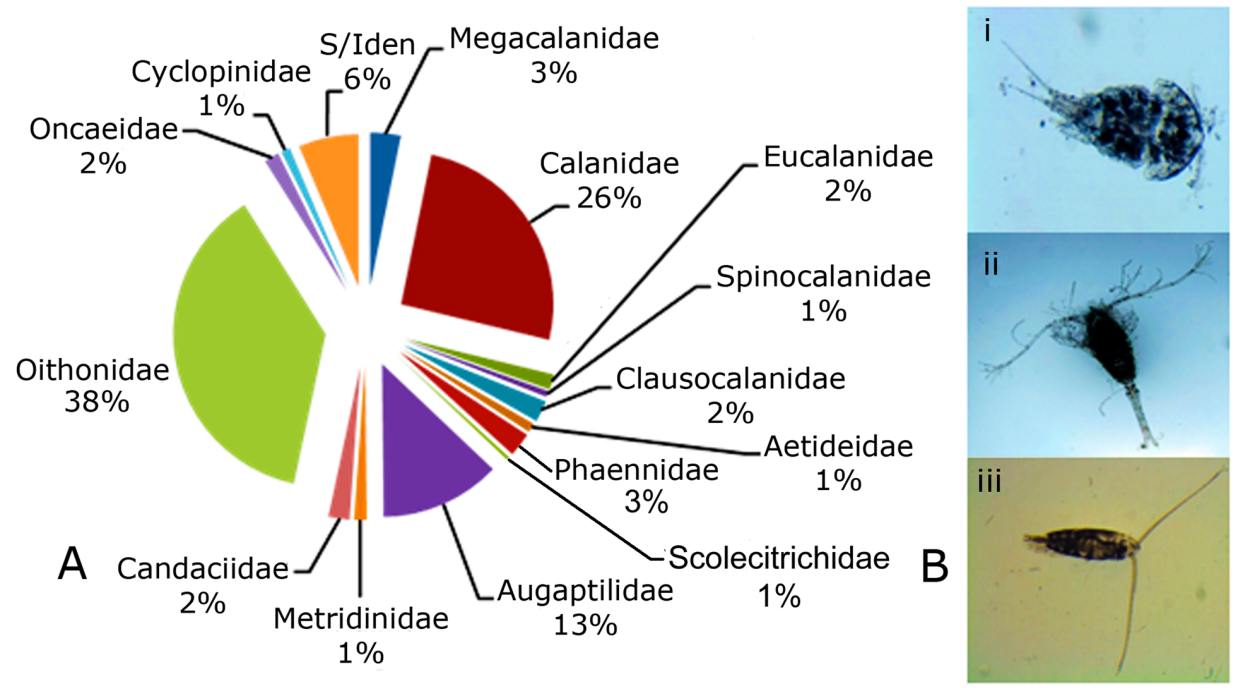

Figure 3. (A) Percentage abundance (\%) of copepods families found in Fíldes Bay. (B) Photograph of the copepods species representatives of the families (i) Augaptilidae, (ii) Oithonidae and (iii) Calanidae / (A) Abundancia porcentual (\%) de las familias de copépodos encontradas en Bahía Fíldes. (B) Fotografía de las especies de copépodos representantes de las familias (i) Augaptilidae, (ii) Oithonidae y (iii) Calanidae

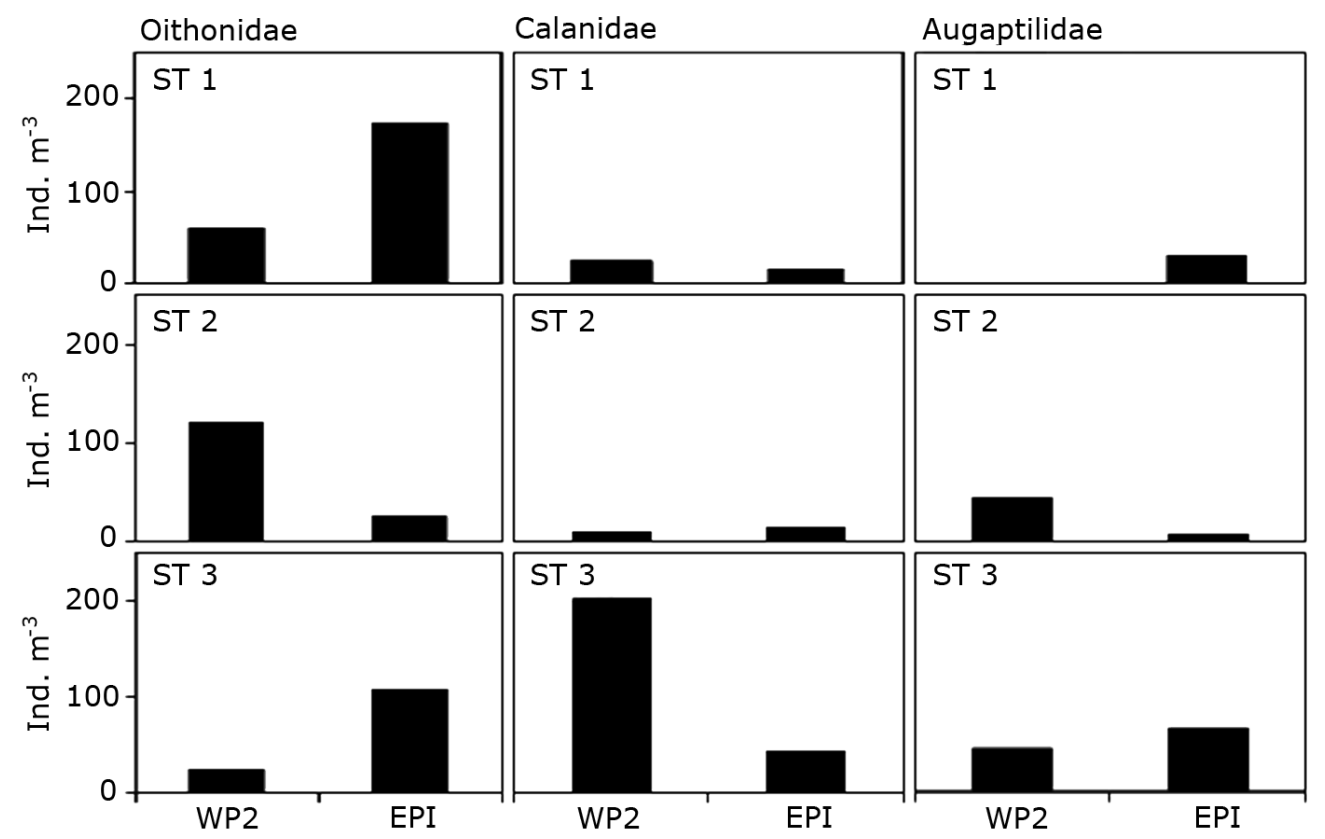

Figure 4. Abundance (ind. $\mathrm{m}^{-3}$ ) of the most commonly found families of copepods at different depths at Stations 1, 2 and 3 in Fíldes Bay / Abundancia (ind. $\mathrm{m}^{-3}$ ) de las familias de copépodos más comúnmente encontrados a diferentes profundidades en las Estaciones 1, 2 y 3 de Bahía Fíldes 
observed, mainly in deeper layers of the water column (Fig. 5).

Cluster analysis and non-metric multidimensional scaling (n-MDS) indicated a greater degree of similarity in the distribution of copepod Families at Station 1 closest to the coast and Station 2 (Fig. 6) at both depths. Station 3 showed a different distribution pattern to the other two Stations and this difference was more pronounced at 0 -

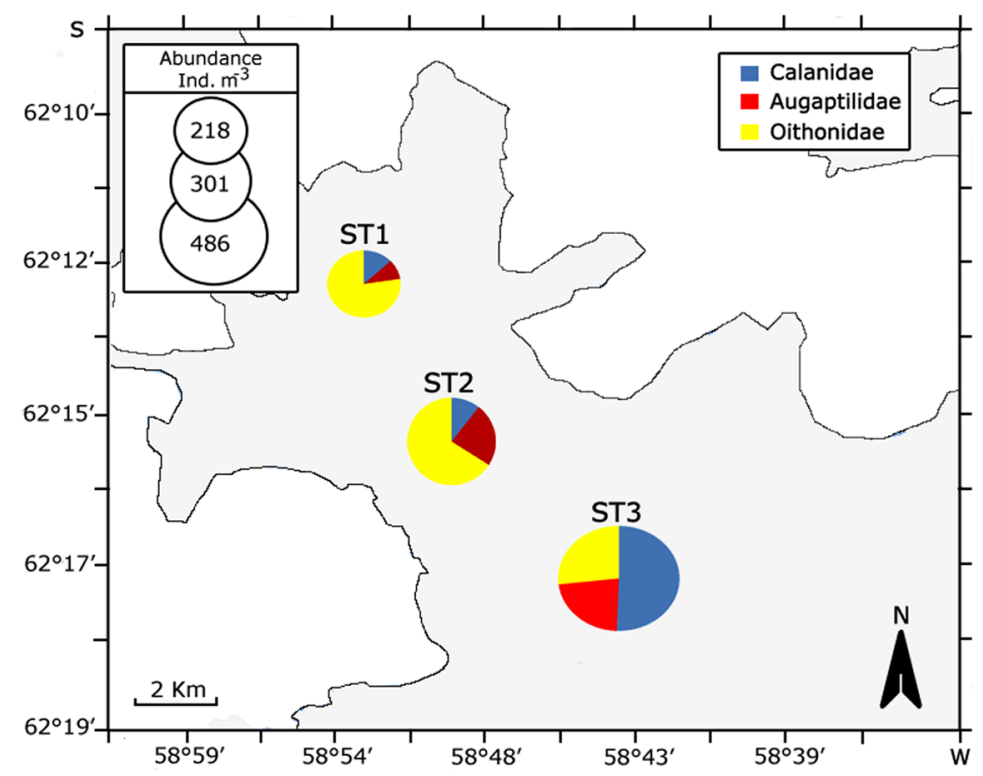

Figure 5. Abundance (ind. $\mathrm{m}^{-3}$ ) of the three most abundant copepods families in the area of study. Station 1 (ST 1), Station 2 (ST 2), Station 3 (ST 3) / Abundancia (ind. $\mathrm{m}^{-3}$ ) de las tres familias de copépodos más abundantes y características de la zona de estudio. Estación 1 (ST 1), Estación 2 (ST 2), Estación 3 (ST 3)
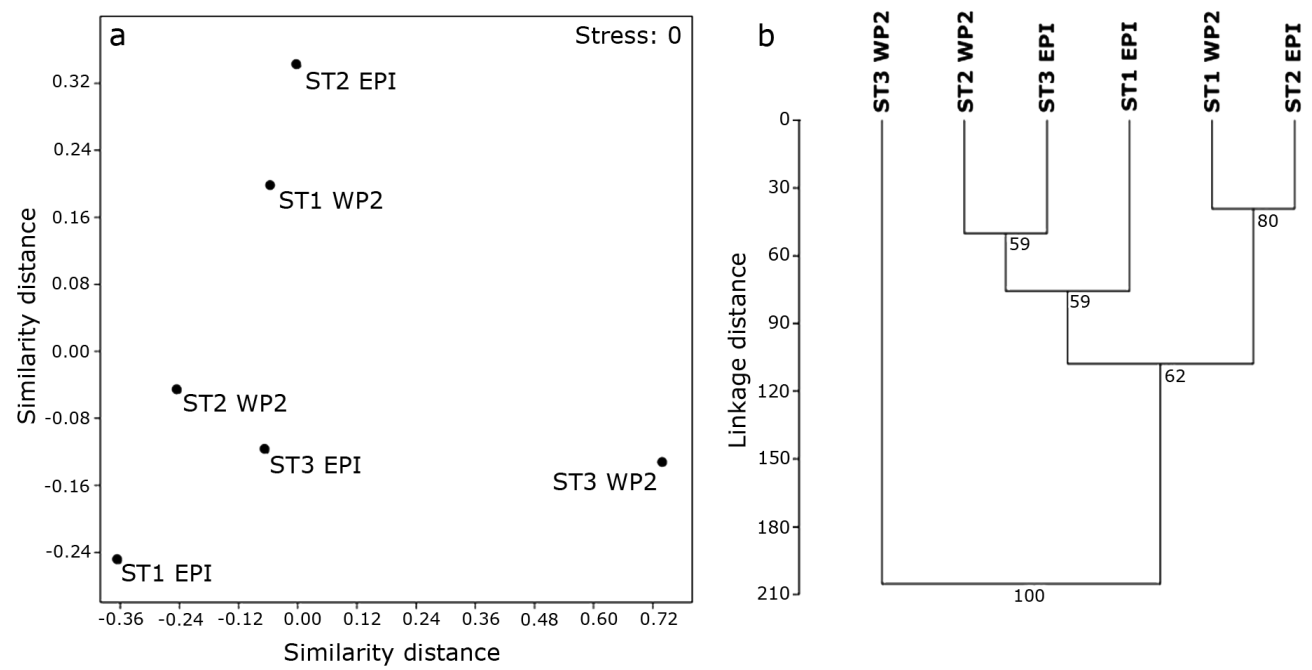

Figure 6. a) Non-metric multidimensional scaling (n-MDS) and b) Dendrogram that shows differences in the abundance (ind. $\mathrm{m}^{-3}$ ) of all copepods families found in all the station and types of net in Fíldes Bay / a) Análisis de escalamiento multidimensional no métrico ( $n$-MDS) y b) Dendrograma que muestran las diferencias en la abundancia (ind. $\mathrm{m}^{-3}$ ) de todas las familias de copépodos encontrados en todas las estaciones y tipos de red para Bahía Fíldes 

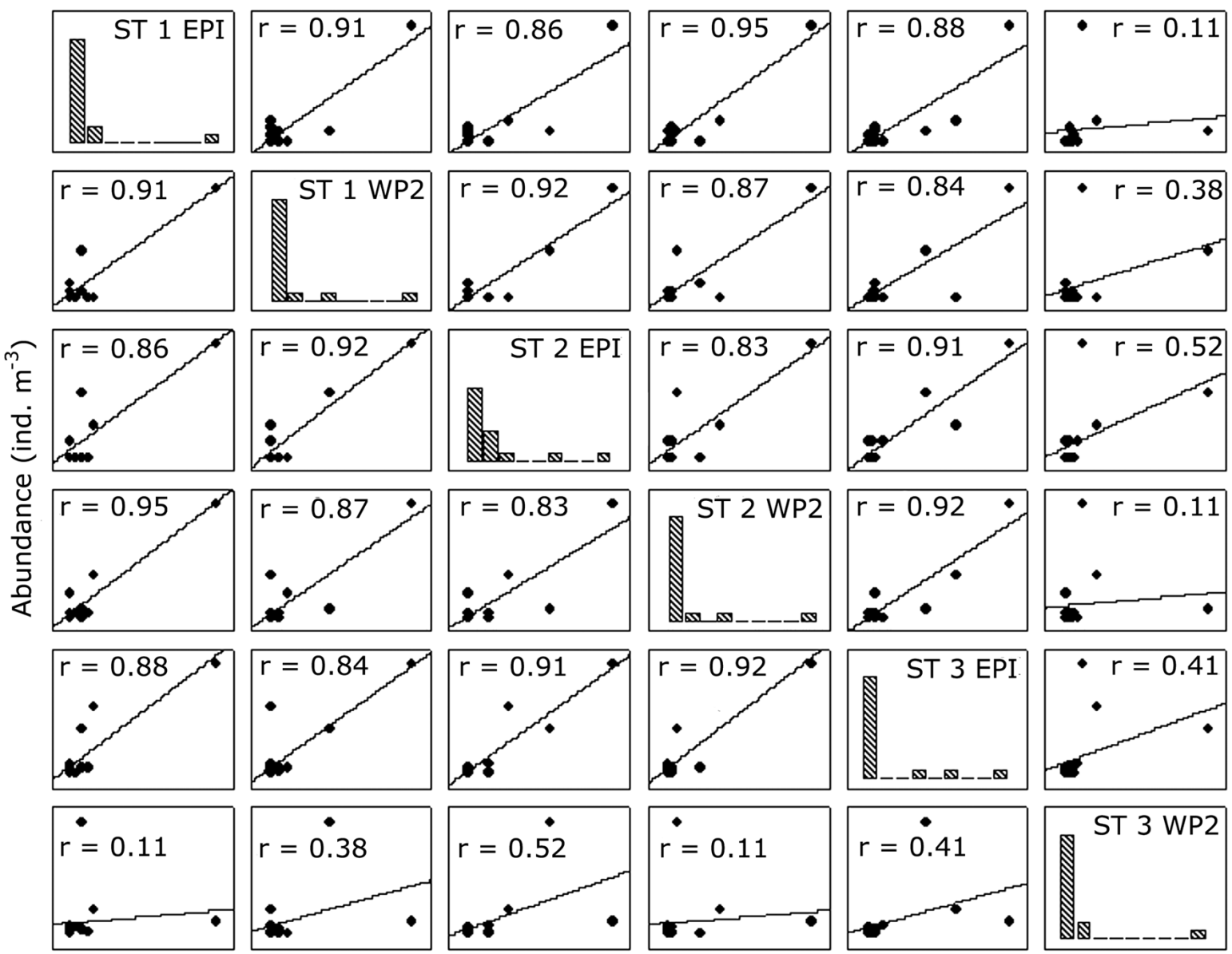

Abundance (ind. $\mathrm{m}^{-3}$ )

Figure 7. Linear correlation between the total abundance (ind. $\mathrm{m}^{-3}$ ) of copepods found in each sampling station and nets. Intermediate histograms show data distribution for each sampling station / Correlación lineal entre la abundancia (ind. $\mathrm{m}^{-3}$ ) de copépodos totales encontrada en cada una de las estaciones y redes de muestreo. Histogramas intermedios muestran estaciones de muestreo y distribución de datos para cada estación

\section{Discussion}

In Fíldes Bay no significant differences in total abundance could be found between the stations and between the surface and 0-15 $\mathrm{m}$ depth for higher zooplankton taxa due to a homogeneous and stable zooplankton structure along all Fíldes Bay. However, a more specific analysis of the distribution pattern of copepods, the predominant taxa, showed differential distribution patterns of abundance along the bay. This is probably due to a high variability in oceanographic conditions within the bay, which would generate different distribution and abundance patterns at depths sampled in this study and at different distances from the shore. In this sense, areas adjacent to the coast, where oceanographic conditions are influenced mainly by the incorporation of fresh water masses and colder at the surface than in areas of the bay close to Bransfield Strait. This could be the factor that generates different distribution patterns along the bay. These differences result in the recognition of three areas within the bay, a colder and more saline coastal area mainly dominated by copepods, amphipods and molluscs in shallow waters and mainly copepods at deeper water layers, a second transitional intermediate zone with variable oceanographic condition between the coast and the area close to 
Bransfield Strait, dominated almost entirely by copepods, both at surface and deep water layers, and finally, a third zone influenced by currents from Bransfield Strait, which its characterized by less colder and less saline waters in surface layers of the water column and mainly dominated by copepods, euphausiids and fish larvae (Table 1). This result differs from others that showed a decrease of close to $34 \%$ in the abundance of copepods from the coastal zone to the zone open to the Bransfield Strait and that taxa like Salpae are the dominant species (Kittel et al. 2001). The different results of these two studies may be due to short-term seasonal changes in the distribution of abundance patterns of zooplankton along the bay, especially during summer months. Such differences highlight the need for more studies of species distribution patterns at different times of year to more fully understand them and the factors that drive the distribution patterns. They also show the extent to which changing oceanographic conditions may rapidly influence species compositions of copepods.

Our study showed that there are significant differences in the composition of the species that dominate within different areas of Fíldes Bay, with the most represented family being the Oithonidae family with an percentage of $38 \%$ abundance, followed by Calanidae family with $26 \%$ of abundance. This raises new questions about the studies of the abundance and distribution of Antarctic copepods, since a study by Walkusz (2004), for Admiralty Bay, close to Fíldes Bay and part of King George Island, reported that representatives of the family Oithonidae were the dominant group, but there are no reports showing Calanidae members as an abundant family in Admiralty Bay. Kittel et al. (2001) found Calanidae at several magnitudes order less than the most abundant copepods family Oithonidae, compared to our study in which Calanidae members were found to be the second important group recognized for Fíldes Bay, particularly in areas close to Bransfield Strait and much low close to coastal areas (Fig. 4).

When considering the distribution of copepods found in Fíldes Bay in our study, and comparing it to studies reported for areas close to the South Shetland Islands, as presented by Zmijewska (1985) and Takahashi et al. (2010), it is interesting to note that that within Fíldes Bay there are differences in species composition compared to the reported by the authors mentioned above. Other authors report that copepods of the genus Oithona sp. and Oncaea sp. are the most dominant species during summer, with February the month where the highest densities of copepods occur within the bay (Chojnacky \& Weglenska 1984). In Drake Passage waters small Calanoid copepods are the most abundant (Thompson et al. 2012), while for the Bransfield Strait, Metrinidae Family followed by copepods of the genus Ctenocalanus are the most dominant with abundances of 6000 ind. $1000 \mathrm{~m}^{-3}$ (Bonicelli et al. 2008). Since Fíldes Bay is open to the waters of Bransfield Strait, the finding of Bonicelli et al. (2008) show that the composition of the families of copepods inside the bay, from the several inlets of Fíldes Bay to the central areas of the bay, differs markedly from and copepods that are abundant in Bransfield Strait, such as the Metrinidae Family which are only found in very low abundance at Station 3 closest to the mouth of the bay. This compositional change could be due to Bransfield Strait which, according to oceanographic data of Fíldes Bay published by Chang et al. (1990), receives a strong influence of water masses from the Weddell Sea where representatives of the Calanidae family are abundant and the Bellinghausen Sea with waters loaded with a wider diversity of copepods that reach the Strait due to the Antarctic Circumpolar Current (Razouls et al. 2000).

These results, combined with those of other studies indicate that Fíldes Bay is an area where the differential distribution of copepod families is the product of the oceanographic variability within the bay from multiple inputs of freshwater from glacier melting and drifting icebergs and the intrusion of more saline water masses from the Bransfield Strait and Weddell Sea (Chang et al., 1990). In this sense, it would be interesting to determine the potential retention factor that could be the bay itself for some copepod species.

This work allowed some development of a baseline necessary to investigate how the zooplankton community changes in the different layers of the water column in a bay with variable oceanographic conditions. Our study showed a very dynamic zooplankton community, specifically in copepods, and a high degree of responsiveness to variable oceanographic influences which could influence the pelagic populations of the study area and other similar areas. The findings of the extent that oceanographic variability from inputs of freshwater from glacier melting and drifting icebergs influenced the composition of the zooplankton species abundances in this study has implications for the potential effects of changes in the Antarctic oceanographic environments if melting patterns change due to climatic influences. 


\section{ACKNOWLEDGMENTS}

Chilean Antarctic Institute (INACH) Project P_01_11, Correos de Chile, Chilean Air Force for logistical support. Marine Research Center CIMARQ and Mr. Pablo Bonati for his logistical support.

\section{LITERATURE CITED}

Battaglia B, J Valencia \& DWH Walton. 2009. Antarctic communities: species, structure and survival, $464 \mathrm{pp}$. Cambridge University Press, Cambridge.

Bonicelli P, J Lopez, D Ochoa, N Shreeve \& S Rachael. 2008. Estructura comunitaria del zooplancton asociada con el fitoplancton y las masas de agua del estrecho Bransfield y la isla elefante durante el verano austral del 2006. Ecología Aplicada 7: 159-164.

Chang KI, HK Jun, GT Park \& EO YS. 1990. Oceanographic conditions of Maxwell Bay, King George Island, Antarctica (Austral summer 1989). Korean Journal of Polar Research 1(1): $27-46$.

Chojnacky J \& T Weglenska. 1984. Periodicity of composition, abundance, and vertical distribution of summer zooplankton (1977/1978) in Ezcurra Inlet, Admiralty Bay (King George Island, South Shetland). Journal of Plankton Research 6(6): 997-1017.

Clarke A \& LS Peck. 1991. The physiology of polar marine zooplankton. In: Sakshaug E, CCE Hopkins \& NA Oritsland (eds). Proceedings of the Pro Mare Symposium on Polar Marine Ecology, Trondheim, 12-16 May 1990. Polar Research 10(2): 355-369.

DiSalvo LH. 1998. Observations on the larval and postmetamorphic life of Choncholepas concholepas (Bruguiére 1978 ) in laboratory culture. Veliger 30: 358-368.

Fontaine M. 1988. Taxonomy and distribution of the Antarctica species groups of the genus Euchaeta (Copepoda, Calanoidea). Antarctic Research Series 47: 27-57.

Hammer O, DAT Harper \& PD Ryan. 2001. PAST: Paleontological statistics software package for education and data analysis. Palaeontologia Electronica 4(1): 9. <http:/ /palaeo-electronica.org/2001_1/past/past.pdf>

Kittel W, J Sicinski, MI Zmijewska, L Bielecka \& K Blachowiak-Samolyk. 2001. Antarctic neritic zooplankton community (Admiralty Bay, King George Islands, South Shetland Islands). Polish Polar Research 22(1): 11-33.

Langdon BQ, RM Ross, TK Frazer \& KL Haberman. 1996. Factors affecting distribution and abundance of zooplankton, whit an emphasis on Antartic krill, Euphausia superba. Antartic Research Series 70: 357-371.
Razouls S, C Razouls \& D De Bovée. 2000. Biodiversity and biogeography of Antarctic copepods. Antarctic Science 12: 343-362.

Sakurai H, T Sato, H Arai, A Takasaki, S Tada, H Hori, I Kimpara, T Matsuyama \& M Kodama. 1996. Habitats of fish and epibenthic invertebrates in Fildes Bay, King George Island, Antarctica. Polar Biology 9: 231-242.

Sangrá P, C Gordo, M Hernández-Arencibia, A MarreroDíaz, A Rodríguez-Santana, A Stegner, A MartínezMarrero, JP Pelegrí \& T Pichon. 2011. The Bransfield current system. Deep Sea Research I 58: 390-402.

Smith DA, EE Hofmann, JM Klinck \& CM Lascara. 1999. Hydrography and circulation of the West Antarctic Peninsula continental Shelf. Deep-Sea Research I 46: 925 949.

Takahashi KT, S Kawaguchi, GW Hoise, T Toda, M Naganobu \& M Fukuchi. 2010. Surface zooplankton distribution in the Drake Passage recorded by Continuous Plankton Recorder (CPR) in late austral summer of 2000. Polar Science 3: 235-245.

Thompson G, EO Dinofrio, VAAlder, KT Takahashi \& GW Hosie. 2012. Copepod distribution in surface waters of the Drake Passage using Continuous Plankton Recorder and a Pump-Net onboard system. Brazilian Journal of Oceanography 60: 367-380.

Walkusz W, S Kwasniewski, K Dmoch, H Hop, MI Zmijewska, L Bielecka, S Falk-Peteren \& J Sicinski. 2004. Characteristics of the Arctic and Antartic mesozooplankton in the neritic zone during summer. Polish Polar Research 25(3-4): 275-291.

Zhou M, Y Zhu, RD Dorland \& CI Measures. 2010. Dynamics of the current system in the southern Drake Passage. Deep-Sea Research I 57: 1039-1048.

Zmijewska MI. 1985. Copepoda in the southern part of Drake Passage in Bransfield Strait during early summer 1983-1984 (BIOMASS-SIBEX, December-January). Polish Polar Research 6(1-2): 79-93.

Zmijewska MI. 1987. Horizontal and vertical distribution of Copepoda in the southern part of the Drake Passage and in the Bransfield Strait (Biomass-Sibex 1983/1984). Polish Polar Research 8(4): 381-390.

Zmijewska MI, J Yen \& L Bielecka. 1999. Size variability in two common Antarctic copepods: Calanoides acutus (Giesbrecht) and Metidia gerlachei (Giesbrecht). Polish Polar Research 20(4): 325-333. 